\title{
Proximate and Sensory Attribute of Instant Wet and Powder Fermented Maize (Ogi) Fortified with Soybean Garlic, Ginger and Date Fruit.
}

\author{
${ }^{* 1}$ Lawal, Rukayat A. ${ }^{2}$ Adebusoye, Michael S. \& ${ }^{1}$ Musa, Hamisu \\ ${ }^{1}$ Department of Food Science and Technology \\ ${ }^{2}$ Department of Nutrition and Dietetics \\ The Federal Polytechnic, Bauchi \\ Bauchi State, Nigeria \\ *Corresponding E-mail: motheofbelievers@gmail.com \\ Phone No: +2348055597101
}

\begin{abstract}
Background: Cereals are generally low in protein particularly the essential amino acids; lysine and tryptophan. These essential amino acids can be compensated for by fortifying ogi (cereal based porridge) with soy beans and improving its shelf life with spices.
\end{abstract}

Objective: To determine the proximate and sensory attribute of wet and reconstituted Ogi powder fortified with soybean, spices and date fruits.

Methods: The ogi was processed by soaking of maize grain in cold water for $72 \mathrm{hrs}$ after which the water was decanted, washed and wet milled with spices in commercial mechanical grater. The resulting pulp was sieved through a $0.9 \mathrm{~mm}$ standard Tyler screen to obtained ogi slurry. Then, soybean was partially defatted with n-hexane. Then, date fruit was cleaned broke and dried in conventional cabinet dryer at $45^{\circ} \mathrm{C}$ for $18 \mathrm{hrs}$ and milled into flour. The slurry was divided into two portions, one part was dried in cabinet drier at $100^{\circ} \mathrm{C}$ for 90mins, cooled and milled into powder and mixed with defatted soybean and date fruit powder. The second portion was packed in cellophane bag and stored in refrigerator prior to use.

Result: The proximate and sensory evaluations were carried out on both samples. The mean compositions were reported as followed; moisture content ranged from $(8.10 \& 10.20)$ crude fat $(5.40 \& 7.60)$, protein (6.82 \& 14.89), Ash (1.68 \& 1.80), carbohydrate (61.21\& 65.80), crude fiber (3.34 \& 4.42) respectively as well as organoleptic properties of both samples.

Conclusion: The high protein content of soy enriched" Ogi powder" would be of nutritional importance in most developing countries like Nigeria where the cost of obtaining high protein food is high.

Keyword: Yellow maize, spices, fortified, date fruits, proximate composition

Aims Research Journal Reference Format:

Lawal, R.A., Adebusoye, M.S. \& Musa, H. (2019): Proximate and Sensory Attribute of Instant Wet and Powder Fermented Maize

(Ogi) Fortified with Soybean Garlic, Ginger and Date Fruit. Advances in Multidisciplinary Research Journal. Vol. 5. No. 1, Pp 55-60 Article DOI: dx.doi.org/10.22624/AIMS/V5N1P3.

Available online at www.aimsjournal.net

\section{INTRODUCTION}

'Ogi' is fermented cereal based porridge. It could be made from maize (Zea mays), millet (Pennisetumglancum) and sorghum (Sorghum bicolor). Its fermentation involves acid bacteria notably Lactobacillus spand various yeasts including Saccharomyces cerivisiae Sanni, Asiedu \& Ayernor [1]. Ogi is a popular breakfast cereal product in West Africa with high acceptability, low cost and shelf life stability characteristics. It is widely consumed by infants, children and adults in Nigeria Mbata, Ikenebomeh \& Alanemen [2]. 
It could be prepared as liquid gruel and consumed sole or with supporting bean cakes or it could be made into stiff consistency (eko or agidi) and consumed with vegetable soups or bean cakes. Lactic acid bacteria convert the carbohydrates in the cereals during ogi production to organic acids which contribute to softness in the product and it's the characteristic flavor and sour taste Oyarekua,[3].

Cereals are generally low in protein particularly the essential amino acids; lysine and tryptophan. These essential amino acids can be compensated for by fortifying cereals products with legumes which are on the other hand high in lysine and tryptophan but low in methionine and cystine which are high in cereals. Soyogi is a cereal- soybean mixture processed into ogi paste. Soybean is an underutilized legume in West Africa which is of great importance due to its high protein content. Protein content in plain ogi is enhanced by its fortification with soybean paste Akanbi, Aarrry, \& Garba [4].

'Ogi' traditionally is prepared by steeping cereal (maize, sorghum, millet) in cold water for three days (72hrs), followed by wet milling and wet sieving through muslin cloth. The filtrate is then allowed to sediment, supernatant is discarded and the sediment is the 'Ogi'. During steeping and sieving of the maize paste, a lot of nutrients including protein, vitamins, and minerals are lost Inyang \& Idoko, [5]. Loss of these nutrients can be minimized by excluding the sieving stage. Spices are culinary/herbs which have aromatic or pungent flavor.

They are dried seeds, fruit, root or vegetable substances used in preparation of soups to enhance the flavor of such food Shakuntala \& Shadaksharaswamy [6]. Spices do not only excite taste, they are composed of high quality phytonutrients, essential oils, antioxidants, minerals and vitamins that are essential for overall health sustenance Umesh, [7]. Ginger (Zingiberofficinale) is a spice native of Asia. Ginger is valued for its wide array of medicinal uses. Ginger contains health benefiting oil such as gingerols and zingerone. Ginger is high in antioxidants which help in preventing cell damage caused by free radicals. Date fruits contain a high percentage of carbohydrate (44.88\%), protein (2.3-5.6) and dietry fiber (6.4-1.5\%). The fat percentage reaches upto (0.2-0.5\%), including 14 types of fatty acids Ajanaku et al; [8].

Garlic (Allium sativumL.) contains at least 33 sulfur compounds, several enzymes and the minerals germanium, calcium, copper, iron, potassium, magnesium, selenium and zinc; vitamins A, B1 and C, fiber and water. It also contains 17 (seventeen) amino acids namely: lysine, histidine, arginine, aspartic acid, threonine, glutamine, proline, glycine, alanine, cysteine, valine, methionine, isoleucine, leucine, tryptophan and phenylalanine Josling, [9]. Typical garlic food preparation such as chopping, mincing and crushing disturbs S-allyl cysteine sulfoxide and exposed it to the allinase enzymes, then quickly converts it to diallylthiosulfinate, which gives off the characteristic aroma in garlic.

The allinase enzyme responsible for diallylthiosulfanate conversion becomes inactivated below a pH of 3.5 or with heating Pedrazza-Chaverri et al; [10]. Although allicin is considered the major antioxidant and scavenging compound, recent studies are showing that other compounds may play stronger roles; such as polar compounds of phenolic and steroidal origin, which offer various pharmacological properties Lanzotti \& Chromat [11]. 


\section{MATERIAL AND METHODS}

\section{Procurement of samples}

The materials used in this study (yellow maize, soybean, ginger, garlic and date fruits) were purchased from Muda Lawan market, Bauchi State, Nigeria.

\section{Preparation samples.}

\section{Preparation of Ogi slurry.}

Ogi slurry was prepared by using a modified method of Odunfa, [19]. Seventy grams $(70 \mathrm{~g})$ of maize, ginger $(10 \mathrm{~g})$, galic $(10 \mathrm{~g})$ were soaked in $250 \mathrm{ml}$ of clean water and allowed to ferment at $28 \pm 2^{\circ} \mathrm{C}$ for $72 \mathrm{hrs}$, after which the water was decanted, washed and wet milled with spices in commercial mechanical grater. The resulting pulp was sieved through a $0.9 \mathrm{~mm}$ standard Tyler screen to obtained ogi slurry. The slurry was divided into two portions. One portion was dried in a conventional cabinet drier at $100^{\circ} \mathrm{C}$ for $90 \mathrm{mins}$. It was cooled to room temperature, milled and packed in air tight polythene bag. Then, second portion was packed in cellophane bag and store in refrigerated prior to use.

\section{Preparation of partial defatted soybeans and date fruit flour}

Soybean seed was processed into defatted flour using the method described by Osho, [14]. Twenty grams of soybeans was cleaned, roasted and dehulled. The bean was milled with attrition miller, partially defatted with n-hexane and cooled to room temperature. Then, the flour was sieved with $400 \mu \mathrm{m}$ fine sieve. Ten grams of date fruits was cleaned broke and dried in conventional cabinet drier at $45^{\circ} \mathrm{C}$ for $18 \mathrm{hrs}$ and milled into flour. The instant ogi powder was blended with defatted soybean and date fruits flour in ratio (70:20:10). The mixture was packaged in polyethylene bag prior to use.

\section{Proximate analysis}

The samples obtained were analyzed for moisture, ash, crude fiber, protein and crude fat using the methods described AOAC [12]. Carbohydrate content was determined by subtracting the sum of the percentage weight of crude protein, crude fiber, ash, fat from 100 percent.

\section{Sensory evaluation of instant Ogi}

Gruel was prepared, by mixing $20 \mathrm{~g}$ of each sample with $80 \mathrm{ml}$ of boiling water. Then, a teaspoonful of sucrose $(9 \mathrm{~g})$ was added to each of the gruels to improve its taste. The samples were then served hot to the panelist Osho; [14]. A 9-point hedonic preference scale (where 9 corresponds to like extremely and 1 to dislike extremely) was used to test the mouth-feel, taste, colour, aroma and overall acceptability of the powder and wet ogi.

\section{Statistical analysis}

The data obtained were subjected to T-test and one-way ANOVA for sensory evaluation of both samples. 


\section{RESULTS}

Table 1: Proximate composition of fortified wet ogi and dried sample (\%)

\begin{tabular}{lll}
\hline Chemical composition & Dried Ogi sample & Wet Ogi sample \\
\hline Moisture content & $8.10 \pm 0.02$ & $10.20 \pm 0.01$ \\
Crude fat & $7.60 \pm 0.012$ & $5.40 \pm 0.03$ \\
Protein & $14.89 \pm 0.01$ & $6.82 \pm 0.01$ \\
Ash & $1.68 \pm 0.06$ & $1.80 \pm 0.02$ \\
Crude fiber & $4.82 \pm 0.04$ & $3.34 \pm 0.01$ \\
Carbohydrate & $65.80 \pm 0.01$ & $61.21 \pm 0.02$ \\
\hline
\end{tabular}

Table 2: Sensory evaluation of wet and dried ogi samples

\begin{tabular}{lll}
\hline Parameters & Wet Ogi sample & Dried Ogi sample \\
\hline Mouth feel & $5.45 \pm 0.01$ & $7.34 \pm 0.03$ \\
Taste & $6.80 \pm 0.05$ & $7.42 \pm 0.02$ \\
Aroma & $5.70 \pm 0.02$ & $7.05 \pm 0.01$ \\
Colour & $5.02 \pm 0.02$ & $6.89 \pm 0.02$ \\
Overall acceptability & $6.00 \pm 0.02$ & $7.32 \pm 0.04$ \\
\hline
\end{tabular}

\section{DISCUSSION}

Ogi powder enriched with defatted soy bean flour and wet ogi slurry observed in this study is in agreement with the observation of Osho; Monayajo; \& Nupo, [14 \& 15] on cassava based products enriched with soybeans, Mouki et al; [16]. Also reported nutritional improvement in the end products of a food enrich with soybean flour. However, there was significant difference in the protein content of ogi powder and wet ogi slurry. The increase in protein content is similar to some other research study in which soy flour was used in products enrichment Jimoh \& Olatidoye, and Kolapo \& Sanni, [17 \& 18].

This increase in protein content of Ogi powder enriched with defatted soy flour has been attributed to the significant quality of protein in soybean seed. Therefore, the high protein content of soy enriched" Ogi powder" would be of nutritional importance in most developing countries like Nigeria where the cost of obtaining high protein food is high.

From the results in Table 2, the panelists were able to distinguish a significant difference $(P<0.05)$ in all attributes among the two samples of wet Ogi and instant Ogi powder. The scores of mouth feel, taste, aroma, color and overall acceptability of wet Ogi was significantly $(P \leq 0.05)$ lower than that of instant ogi powder blended with defatted soy bean and date fruit flour. 


\section{CONCLUSION}

This study indicated that, defatted soybean enriched ogi powder can be used to provide alternative, cheap and nutritious food that can be used to uplift social economic condition as well as people associated with protein malnutrition deficiency as a result of increase in protein in dry instant ogi powder. There was significant difference in all the sensory attribute of the gruel of instant ogi powder blended with defatted soybean and date fruit flour. However, the gruel prepared from instant ogi powder enrichment was appreciated by panelist in term of overall acceptability.

\subsection{Recommendations}

Based on the findings fro the research, we recommend as follows:

- $\quad$ Ogi should be processed (dried) into flour (instant) so to increase the shelf life

- Ogi should be fortified with defatted soybean, date fruit flour and spices (ginger and garlic) to improve the nutrient contents and health beneficial substances.

- Fortified instant ogi powder should be consumed by both adult and children due to its rich nutrient value.

\section{Acknowledgement}

The authors sincerely appreciate the joint effort of ND II Food Science and Technology and HND I Nutrition and Dietetics of Federal Polytechnic Bauchi, Bauchi State Nigeria. For job well done.

\section{REFERENCES}

1. Sanni, A.I. Asiedu M. \& Ayernor G.S. (2001). Influence of processing conditions on the nutritive value of ogi baba, Nigerian fermented sorghum gruel. Plant Foods Human. Nutrition.। 2001; 56:217; 223

2. Mbata, T.I. Ikenebomeh, M.J. \& Alanemen J.C. (2009). Studies on the microbiological, nutrient composition and anti nutritional contents of fermented maize flour fortified with bambara groundnut (Vigna subterranean L.). African Journal of Food Science ; 3(6): 165 - 171.

3. Oyarekua, M.A. (2011). Evaluation of nutritional and microbiological status of cofermented cereals/cowpea 'Ogi'. Agricultural and Biological Journal of North America;

2(1):61 - 73 .

4. Akanbi, B.O, Aarrry, O.O. \& Garba S.A. (2010). Quality assessment of selected cereal- soybean mixtures in 'ogi' production. New York Science journal, 3, (10):17- 26.

5. Inyang, C.U. \& Idoko C.A. (2006). Assessment of the quality of ogi made from malted millet. African Journal of Biotechnology, 5(22): 2334- 2337.

6. Shakuntala N. \& Shadaksharaswamy M. (2008). Spices. In: Foods Facts and principles. $3^{\text {rd }}$ edition. New Age International Itd publishers, Pp110 - 112.

7. Umesh R. (2014). Power your diet. www.nutrition-and - you.com Date retrieved:27-12-2014. www.bungeservices.com/iri/go

8. Ajanaku, K.O. Ajanaku CO, Edobor O. \& Nwiyi O.C. Nutritive value of sorghum ogi fortified with groundnut seeds. American Journal of Food Technology 2012; 7: $82-88$.

9. Josling, P.A. (2005). The heart of garlic Nature's aid to healing the human body, HEC Publishing, Chicago Illinois. 20pp.

10. Pedrazza-Chaverri J, Tapia E, Medina-Campos, O.N, de Los Angeles Granados M. \& Franco, M. (2006). Garlic prevents hypertension induced by chronic inhibition of nitric oxide synthesis. Life Sci. 62:71-7

11. Lanzotti, V. \& Chromat. A. (2006). The analysis of onion and garlic. Journal of Food Science and Technology, 12(1):3-22.

12. AOAC, (1995). Official method analysis. Association of official analytical chemists, Washington DC.1995; 63: 4125 - 4142

13. Okoye, J.I., Nkwocha, A.C. and Agbo, A.O. 2008. Nutrient Composition and Acceptability of Soy-Fortified Custard. Continental Journal of Food Science and Technology, 2: 37-351 44. 
14. Osho, S.M. (2003). The processing and acceptability of a fortified cassava-based product (gari) with soybean. Journal of Food and Nutrition, 33,278-283.

15. Monayajo, S.A, \&Nupo, S.S. (2011). Nutrient composition and acceptability of "Pupuru"

16. Muoki, P.N., Kock, L.H., \& Emmambux, M.N (2012).Effect of soybeans addition and Heatfortified with soy flour. Journal of Agriculture and Veterinary Sciences. V (3), 346-423.

17. Jimoh, K.O., \& Olatidoye, O.P.(2009). Evaluation of physicochemical properties and rheological characteristics of soybean fortified yam flour. Journal of Applied Bioscience. V (31), 70706.

18. Kolapo, A.L., \& Sanni, M.O. (2005). Processing and characteristics of soybeans-fortified tapioca, Journal of Women in Technology Education.4, 59-66.

19. Odunfa, S.A. (1985). African fermented foods. In.: Wood,BJ (ed) Microbiology of fermented Foods. Vol.2.Elsevier applied Science publishers. London, New York. 